\title{
PERANCANGAN ROBOT VACUUM CLEANER
}

${ }^{1}$ Hendra Gunawan

Sekolah Tinggi Teknologi Indonesia, Jurusan Teknik Informatika

E-mail: ${ }^{1}$ hendratay96@gmail.com

\begin{abstract}
ABSTRAK
Robot merupakan salah satu bidang teknologi yang dapat meringankan pekerjaan manusia. Sebagian orang menggunakan sapu membersihkan rumah, namun penggunaan sapu membersihkan rumah akan menguras waktu dan tenaga manusia. Jika ruangan kecil, maka tidak terlalu menguras waktu dan tenaga. Namun apabila ruangan besar, maka akan menguras banyak waktu dan tenaga. Maka pada penelitian ini dibuatlah sebuah robot vacuum cleaner yang dapat otomatisasi sendiri dan dapat dikontrol oleh pengguna.

Dalam melakukan penelitian ini, metode yang digunakan adalah studi literature dan observasi untuk pengumpulan data dan model waterfall untuk pengembangan perangkat lunak. Sistem dimodelkan dengan menggunakan Flowmap dan Use case diagram. Hasil dari penelitian ini adalah dibangunnya suatu perangkat keras dan perangkat lunak untuk meringankan pekerjaan manusia, yang dibuat dengan bahasa pemograman $\mathrm{c} / \mathrm{c}++$ untuk robot dan java untuk aplikasi android. Diharapkan dengan adanya robot dan aplikasi android yang dibangun ini akan mempermudah pembersihan ruangan atau meringankan pekerjaan manusia.
\end{abstract}

Kata kunci: robot, vacuum cleaner, otomatisasi, pengontrolan, android

\section{PENDAHULUAN}

Pada saat ini, bidang teknologi adalah bidang yang berkembang paling pesat dibandingkan dengan bidang lainnya. Perkembangan bidang teknologi saat ini sangat membantu manusia dalam kehidupan sehari-hari.Robot adalah salah satu bidang teknologi yang dapat membantu atau meringankan pekerjaan manusia dalam kehidupan sehari-hari. Contoh robot yang dapat membantu atau meringankan perkerjaan manusia adalah robot vacuum cleaner.

Sebagian orang pada umumnya menggunakan sapu untuk membersihkan debu atau sampah yang terdapat dilantai. Namun ada juga yang menggunakan vacuum cleaner sebagai pembersih debu atau sampah yang terdapat lantai. Membersihkan ruangan dengan sapu dan vacuum cleaner masih membutuhkan tenaga manusia dan sangat menguras waktu dan tenaga manusia karena menggunakan waktu dan tenaga manusia untuk mengoperasikannya. Jika ruangan yang ingin dibersihkan kecil, maka tidak terlalu menguras waktu dan tenaga manusia, namun jika ruangan yang ingin dibersihkan besar, maka akan sangat menguras waktu dan tenaga manusia.Sudah ada banyak robot vacuumcleaneryang 
diciptakan untuk membantu membersihkan debu atau sampah pada ruangan. Namun sebagian besar robot vacuum cleaner yang ada dipasaran terlalu mahal untuk dibeli dan tidak menggunakan algoritma dalam navigasinya.

Dalam jurnal Afwan Zikri, Anton Hidayat dan Derisma yang berjudul "Rancang Bangun Robot Vacuum Cleaner Berbasis Mikrokontroler" menyimpulkan bahwa robot yang dirancang yang menggunakan logika fuzzy, tingkat kebersihan maksimal yang dicapai olehnya dalam selang waktu rata-rata 1 menit 11 detik adalah 77,4\%. Dengan daya 2 buah baterai sebesar 9,6V(3000mAH), vacuumcleaner hanya dapat berfungsi secara baik selama 10 menit. Dan disarankan untuk menggunakan baterai lipo (lithium polymer) atau jenis baterai lainnya untuk efisiensi kerja robot dalam jangka waktu yang cukup lama

Dalam jurnal Setya Ardhi, S.T.,M.Kom, Dr. Ir. Hari Sutiksno M.T. yang berjudul "Perancangan dan Pembuatan Prototipe Alat Pembersih Lantai dengan Kendali dari Jaringan Bluetooth" menyatakan robot yang dibuat adalah sebuah prototipe robot penyedot debu dimana system mekaniknya dengan mangadopsi sistem mobil remote controller pada umumnya dan memadukan sistem pengendali Bluetooth dari aplikasi Android yang dibuat dengan tujuan bisa mengendalikan robot tersebut dengan jarak yang cukup jauh dan nantinya remote controller akan digantikan oleh pengendali dari aplikasi Android dengan jaringan sinyal Bluetooth. Jadi penulis mengartikan dengan robot yang dirancang, pengguna dapat mengontrol robot vacuumcleaner dari jauh untuk membersihkan tempat-tempat tertentu untuk menghemat daya baterai.

Berdasarkan penelitian-penelitian diatas, penulis mendapatkan sedikit gambaran apa yang akan di rancang, penulis bermaksud untuk merancang sebuah robot vacuumcleaner yang dapat membersihkan lantai ruangan secara bersih untuk meringankan pekerjaan manusia dengan menggunakan Arduino Uno sebagai otak robot vacuum cleaner dan dapat dikontrol oleh manusia dengan handphone berbasis android.

\section{KAJIAN PUSTAKA}

a. Vacuum Cleaner

Penyedot debu, juga dikenal sebagai penyapu atau hoover, adalah alat yang menggunakan pompa udara (kipas sentrifugal, kecuali beberapa model yang paling tua), untuk membuat vakum parsial untuk menyedot debu dan kotoran, biasanya dari lantai, dan dari permukaan lain seperti jok dan gorden.

Kotoran dikumpulkan oleh kantong debu atau siklon untuk pembuangan selanjutnya. Penyedot debu, yang ada dalam berbagai ukuran dan model perangkat genggam bertenaga baterai kecil, model tabung beroda untuk penggunaan di rumah, pembersih vakum sentral dalam negeri, peralatan industri stasioner besar yang dapat menangani beberapa ratus liter debu sebelum dikosongkan, dan truk vakum self-propelled untuk pemulihan tumpahan besar atau pengangkatan tanah yang terkontaminasi. Ada vacuum cleaner khusus dapat digunakan untuk menyedot debu dan cairan. 


\section{b. Arduino Uno}

Arduino Uno berukuran sebesar kartu kerdit. Walaupun berukuran kecil seperti itu, papan tersebut mengandung mikrokontroler dan sejumlah input/output $(I / O)$ yang memudahkan pemakai untuk menciptakan berbagai proyek elektronika yang dikhususkan untuk menangani tujuan tertentu. Bagian-bagin di Arduino Uno yang perlu diketahui ditunjukkan di Gambar 1

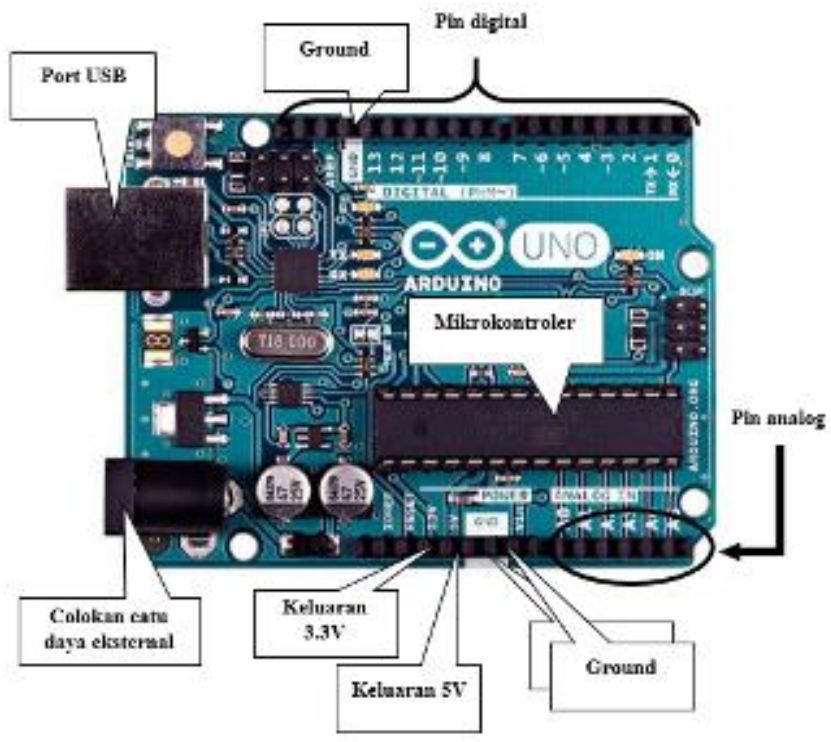

Gambar 1 Arduino Uno

Penjelasan bagian masing-masing seperti berikut:

1. Port USB digunakan untuk menghubungkan Arduino Uno dengan komputer, melalui sepsang kabel USB.

2. Colokan catu daya eksternal digunakan untuk memasok sumber daya listrik untuk Arduino Uno ketika tidak dihubungkan ke komputer. Jika Arduino Uno dihubungkan ke komputer melalui kabel USB, pasokan daya listrik diberi oleh komputer.

3. Pin digital mempunyai label 0 sampai dengan 13. Disebut pin digital karena mempunyai isyarat digital, yakni berupa 0 atau 1 . Dalam praktik, nilai 0 dinyatakan dengan tegangan $0 \mathrm{~V}$ dan nilai 1 dinyatakan dengan tegangan $5 \mathrm{~V}$.

4. Pin analog berarti bahwa pin-pin ini mempunyai nilai yang bersifat analog (nilai yang berkesinambungan). Dalam program, nilai setiap pin analog yang berlaku sebagai masukan (hasil dari sensor) berkisar antar 0 sampai dengan 1023.

5. Mikrokontroler yang digunakan di Arduino Uno adalah Atmel AVR Atmega328P-PU.

6. Ada dua pin yang dapat digunakan untuk memasok catu daya ke komponen elektronis yang digunakan dalam mengangani proyek, 
misalnya sensor gas, sensor jarak, dan relai. Tegangan yang tersedia adalah $3,3 \mathrm{~V}$ dan $5 \mathrm{~V}$. Komponen-komponen elektronis yang diberi tegangan oleh Arduino Uno adalah yang mermerlukan arus kecil. Sebagain contoh motor DC yang menarik arus lebih dari 500mA harus menggunakan catu daya tersendiri.

Arduino Uno dilengkapi dengan static random-access memory (SRAM) berukuran $2 \mathrm{~KB}$ untuk memegang data, Flash memory berukuran $32 \mathrm{~KB}$, dan erasable programmable read-only memory (EEPROM). SRAM digunakan untuk menampung data atau hasil pemrosesan data selama Arduino menerima pasokan catu daya. Flash memory untuk menaruh program yang Anda buat. EEPROM digunakan untuk menaruh program bawaan dari Arduino Uno dan sebagaian lagi dapat dimanfaatkan menaruh data milik Anda secara permanen.

\section{c. Android}

Android adalah nama software yang dipakai pada perangkat mobile yang mencakup berbagai komponen, yaitu sistem operasi, middle-ware dan aplikasi kunci yang dirilis oleh Google. Jadi, Android ini mencakup keseluruhan aplikasi, mulai dari sistem operasi hingga pengembangan aplikasi itu sendiri. Dan pengembangan aplikasi pada platform Android ini menggunakan dasar Bahasa pemrograman Java. Platform pengembangan aplikasi Android yang merupakan bagian dari Android memiliki lisensi open-source atau terbuka, sehingga Anda dapat membangun aplikasi yang kaya dan inovatif. Apabila Anda ingin mengetahui atau melihat kode program yang digunakan, atau bahkan lebih daripada itu, diperbolehkan. Anda juga bisa memodifikasi sistem operasi Android tersebut, dan hal itu legal. Kalau mau melihat sourceAndroid, Anda bisa melihat pada halaman repository untuk mencari source code-nya di alamat http://source.android.com/.

Kernel Linux dipilih oleh tim pengembang tersebut dengan beberapa alasan, antara lain:

1. Security, kernel Linux memiliki pengaturan keamanan yang baik antara sistem dan aplikasi.

2. Manajemen memori, kernel Linux dapat mengatur manajemen memori dengna lebih baik, sehinggan lebih hemat saat melakukan pengembangan aplikasi.

3. Manajemen proses, kernel Linux dapat mengatur proses dan resource dengan lebih baik, sehinggan memudahkan pengaturan untuk menjalankan aplikasi.

4. Network stack, kernel Linux dapat mengatur komunikasi jaringan.

5. Driver, kernel Linux menjamin sesuatu dapat berjalan dengan baik, sehingga pabrikan hardware Android bisa mudah dikerjakan.

Framework atau kerangka kerja sistem operasi Android dikembangkan berdasarkan kernel Linux dengan berbagai fitur tambahan. Fitur-fitur ini dikembangkan secara open-source pula sehingga Anda dapat menambahkan atau memodifikasi sendiri. 
Berbagai fitur yang ada, antara lain:

1. Android run-time, terdiri atas libraryJava dan Dalvikvirtual machine.

2. Open Gl (graphics library), merupakan API (Application Program Interface) yang digunakan untuk membuat grafis 2D dan 3D.

3. WebKit, merupakan engine dari web browser yang dapat digunakan untuk menampilkan isi website dan menyederhanakan tampilan dari proses loading.

4. SQLite, merupakan engine dari relasional database yang dapat diintegrasikan dengan aplikasi.

5. Media framework, merupakan library yang digunakan untuk menjalankan dan merekam file audio atau video.

6. SSL (Secure Socket Layer), merupakan library yang digunakan untuk keamanan internet (internet security).
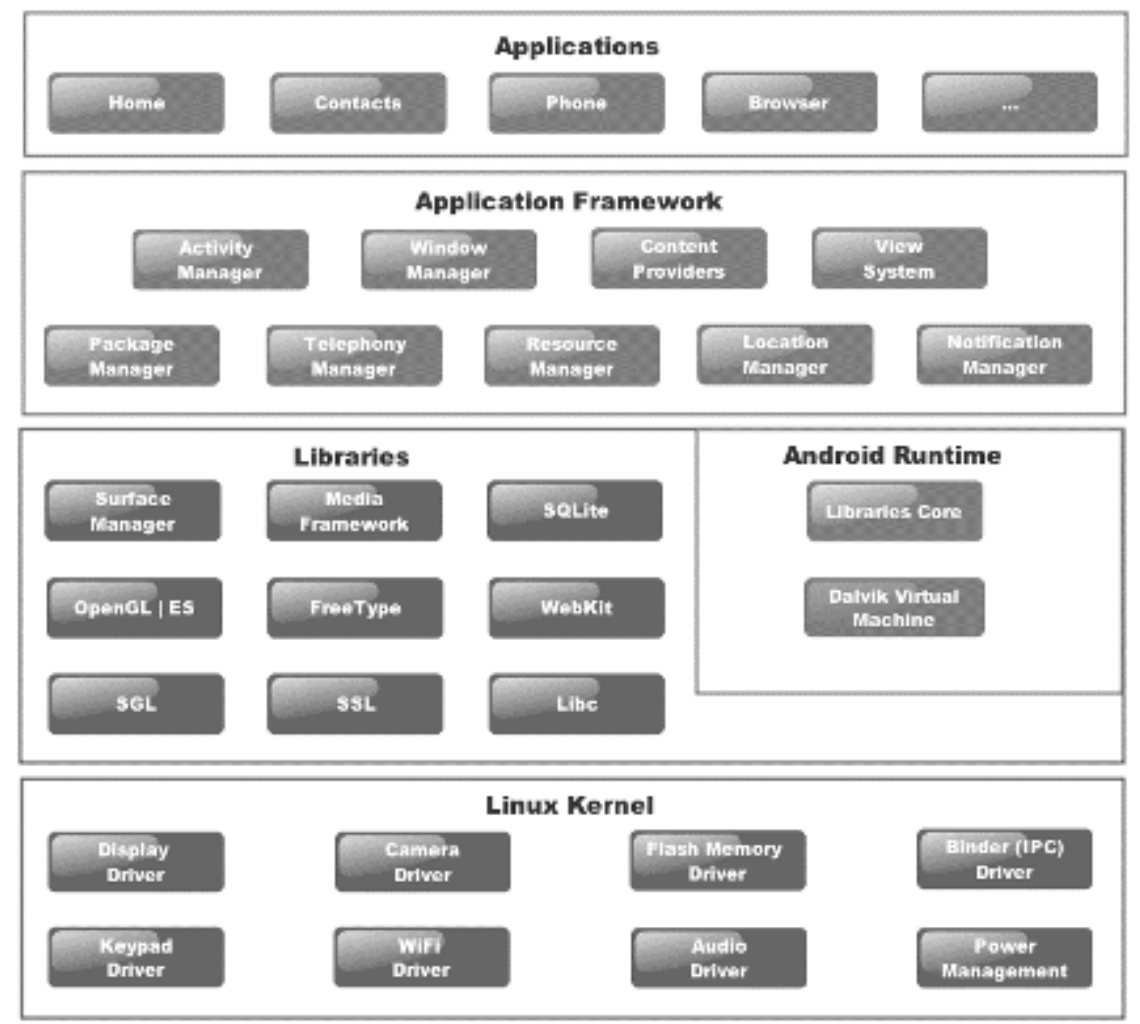

Gambar 2 Android Library

Berbagai fitur-fitur yang ada pada library yang dapat digunakan secara langsung, antara lain:

1. Acitivity Manager, digunakan untuk manajemen siklus hidup dari activity. 
2. Telephony Manager, digunakan untuk akses layanan telepon juga informasi daftar kontak, seperti nomor telepon, alamat, dan lain sebagainya.

3. ViewSystem, digunakan untuk menangani view dan layout tampilan UI (user interface).

4. LocationManager, digunakan untuk menandai lokasi geografis pemegang device.

\section{METODOLOGI PENELITIAN}

a. Metode Pengumpulan Data

1. Metode Studi Literatur

Melakukan pengumpulan data-data atau sumber-sumber yang berhubungan dengan bidang teknologi atau berhubungan dengan judul tugas akhir yang bertujuan untuk membuat laporan dan juga untuk menambah pengetahuan tentang bidang elektronika ataupun robot.

2. Metode Observasi

Melakukan observasi terhadap robot yang sedang di uji untuk mengetahui kecocokan perancangan ataupun algoritma dengan keinginan pengguna.

b. Metode Pengembangan Perangkat Lunak

Metode Pengembangan Perangkat Lunak yang digunakan dalam membangun sistem ini menggunakan model Waterfall (Classic Life Cycle).

\section{HASIL DAN PEMBAHASAN}

Pada perancangan robot vacuum cleaner dibutuhkan sebuah gambaran aliran listrik yang berguna untuk memudahkan instalasi komponen-komponen robot. Perancangan sistem elektronik atau gambaran aliran listrik ini terdiri dari komponen-komponen robot direct currentyaitu Arduino Uno, motor driver 1298n, motor dc,limitswitch sensor, bluetooth hc-05, lcd display, button, relay $5 \mathrm{v}$, vacuum cleaner. 


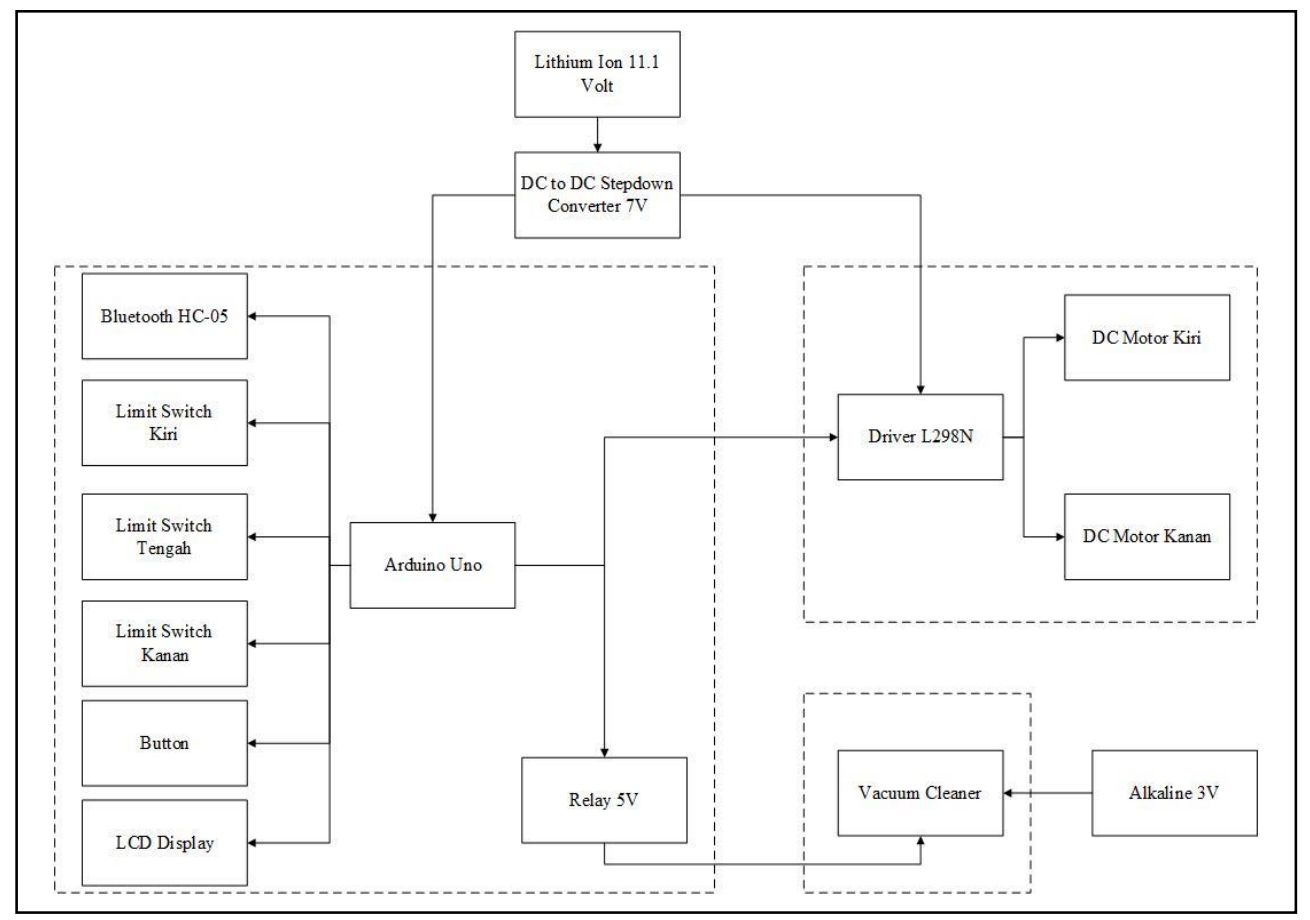

Gambar 4 Diagram Sistem Elektronik Robot

Perancangan robot vacuum cleaner juga membutuhkan perancangan sistem mekanik yang merupakan perancangan tempat letak komponen robot ataupun body robot. Perancangan sistem mekanik terdiri dari body lantai 1, body lantai 2, body lantai 3.

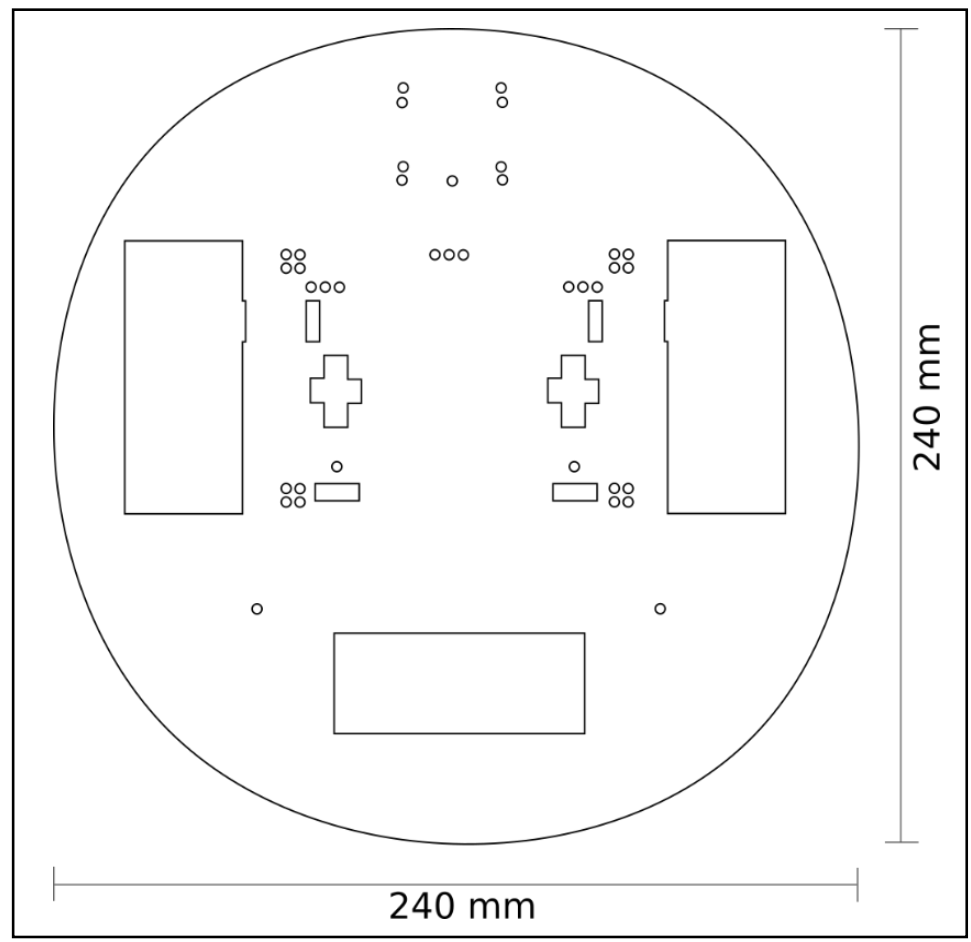

Gambar 5 body lantai 1 
Pada body lantai 1 akan diletakkan komponen robot seperti motor DC, roda, 3 limit switch sensor, roda castor nylon, dan vacuum cleaner. Material body lantai 1 adalah akrilik yang ketebalannya $3 \mathrm{~mm}$. Ukuran lebar atau diameternya adalah 240mmx240mm. Dan ukuran lubang untuk meletakkan baut adalah $3 \mathrm{~mm}$.

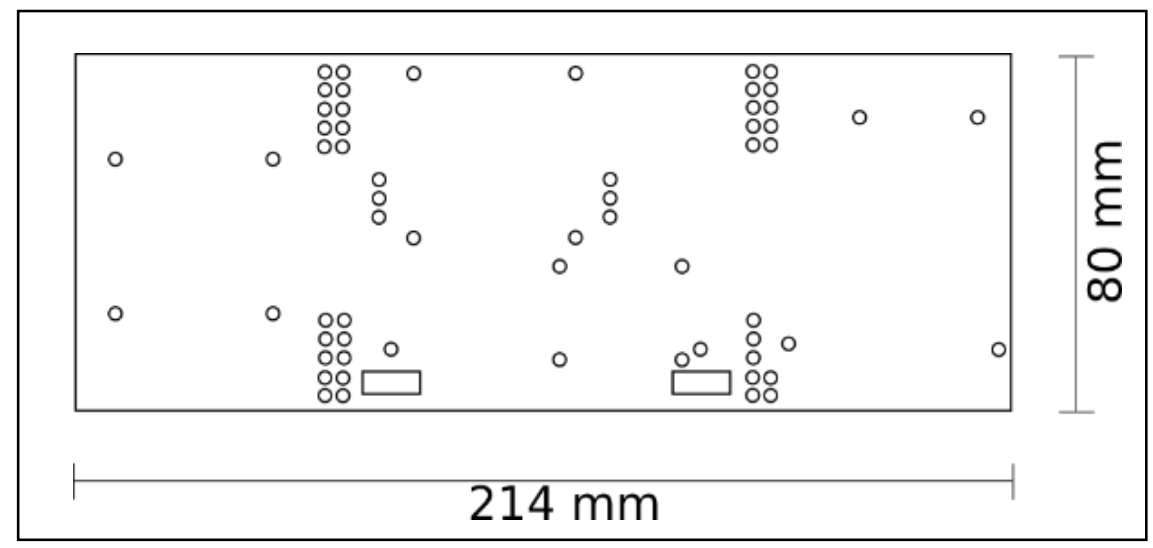

Gambar 6 body lantai 2

Pada body lantai 2 akan diletakkan komponen robot seperti Arduino uno, motor driver 1298n, relay 5v, breadboard dan Bluetooth HC-05. Material body lantai 2 adalah akrilik yang ketebalannya $3 \mathrm{~mm}$. Ukuran lebar atau diameternya adalah 214mmx80mm. Dan ukuran lubang untuk meletakkan baut adalah 3mm.

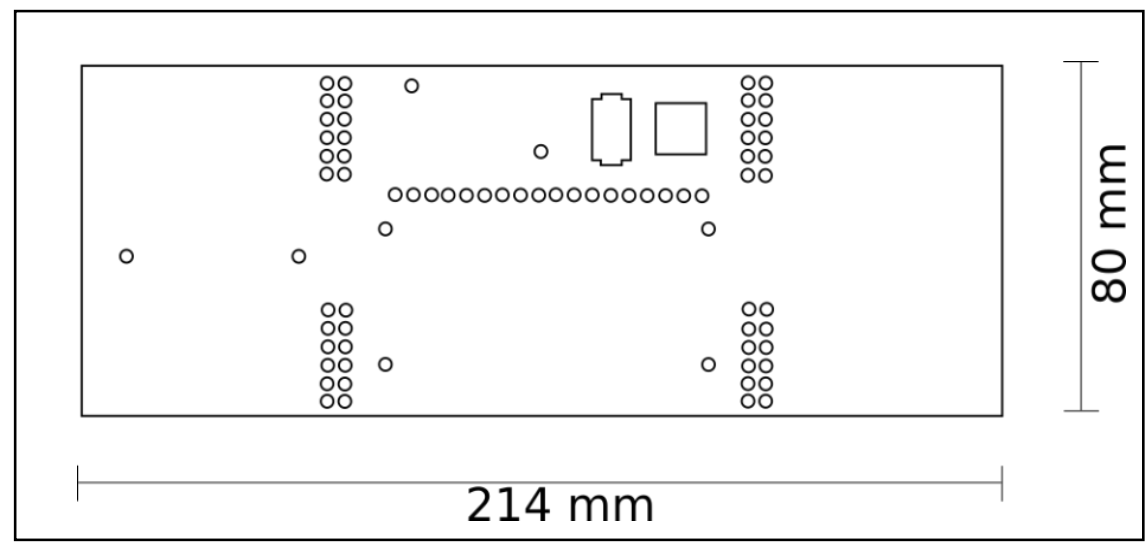

Gambar 7 body lantai 3

Pada body lantai 3 akan diletakkan komponen robot seperti lcd (liquid crystal display), baterai lithium ion $11.1 \mathrm{~V}$, DC to DC step down converter, saklar, dan tombol auto. Material body lantai 2 adalah akrilik yang ketebalannya $3 \mathrm{~mm}$. Ukuran lebar atau diameternya adalah 214mmx80mm. Dan ukuran lubang untuk meletakkan baut adalah $3 \mathrm{~mm}$. 
Use Case Diagram di sini digunakan untuk memodelkan sistem robot vacuum cleaner dengan cara menggambarkan behavior / kelakuan sistem yang akan dibuat. Use Case Diagram di sini berguna untuk mengetahui fungsi apa saja yang ada di dalam sebuah sistem dan siapa saja yang berhak menggunakan fungsi-fungsi tersebut.

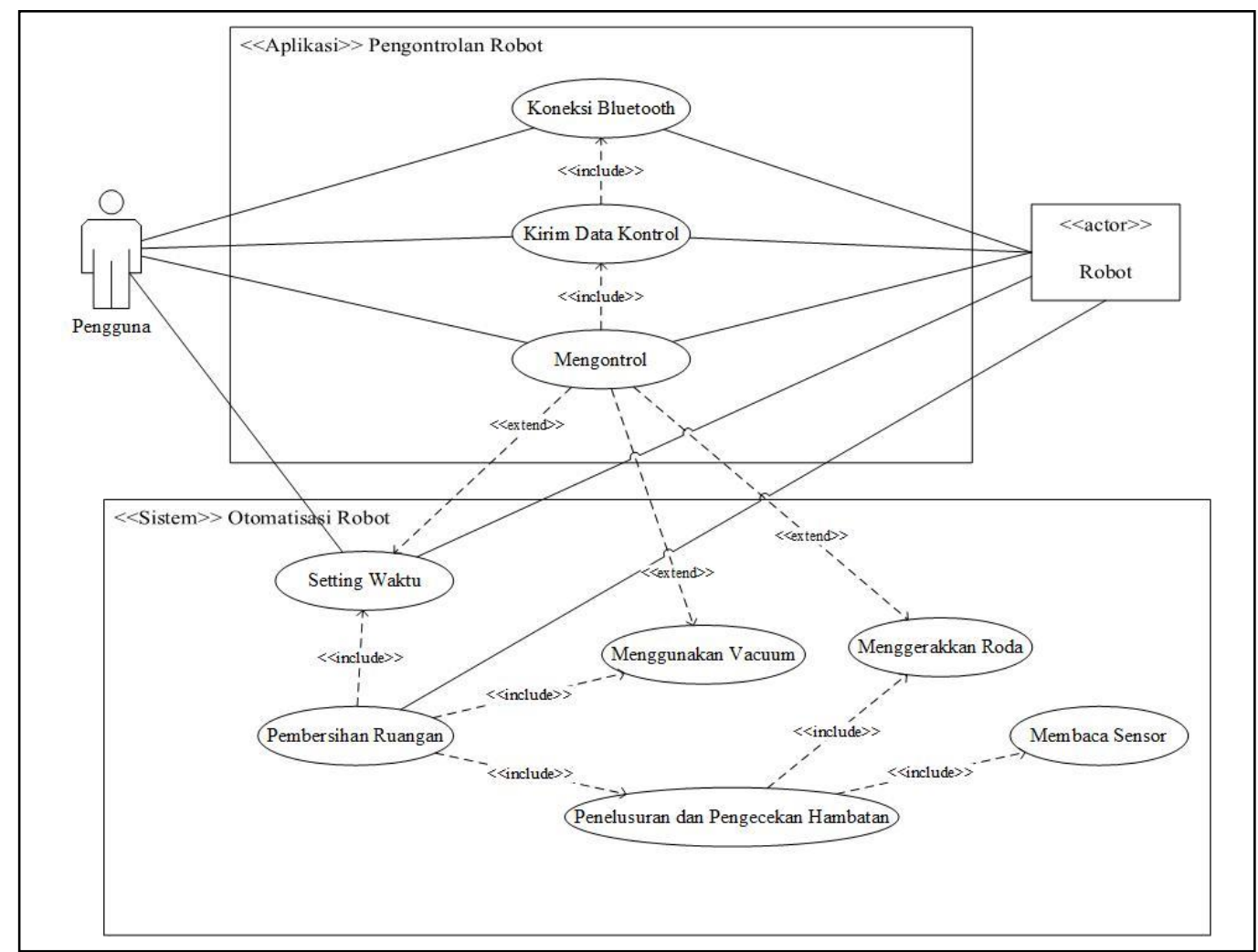

Gambar 8 Use case diagram

Flowchart di sini juga digunakan untuk memodelkan sistem robot vacuum cleaner dengan menggambarkan alur atau rangkaian proses keseluruhan sistem. Dari menghidupkan robot sampai otomatisasi robot atau pengontrolan robot. 


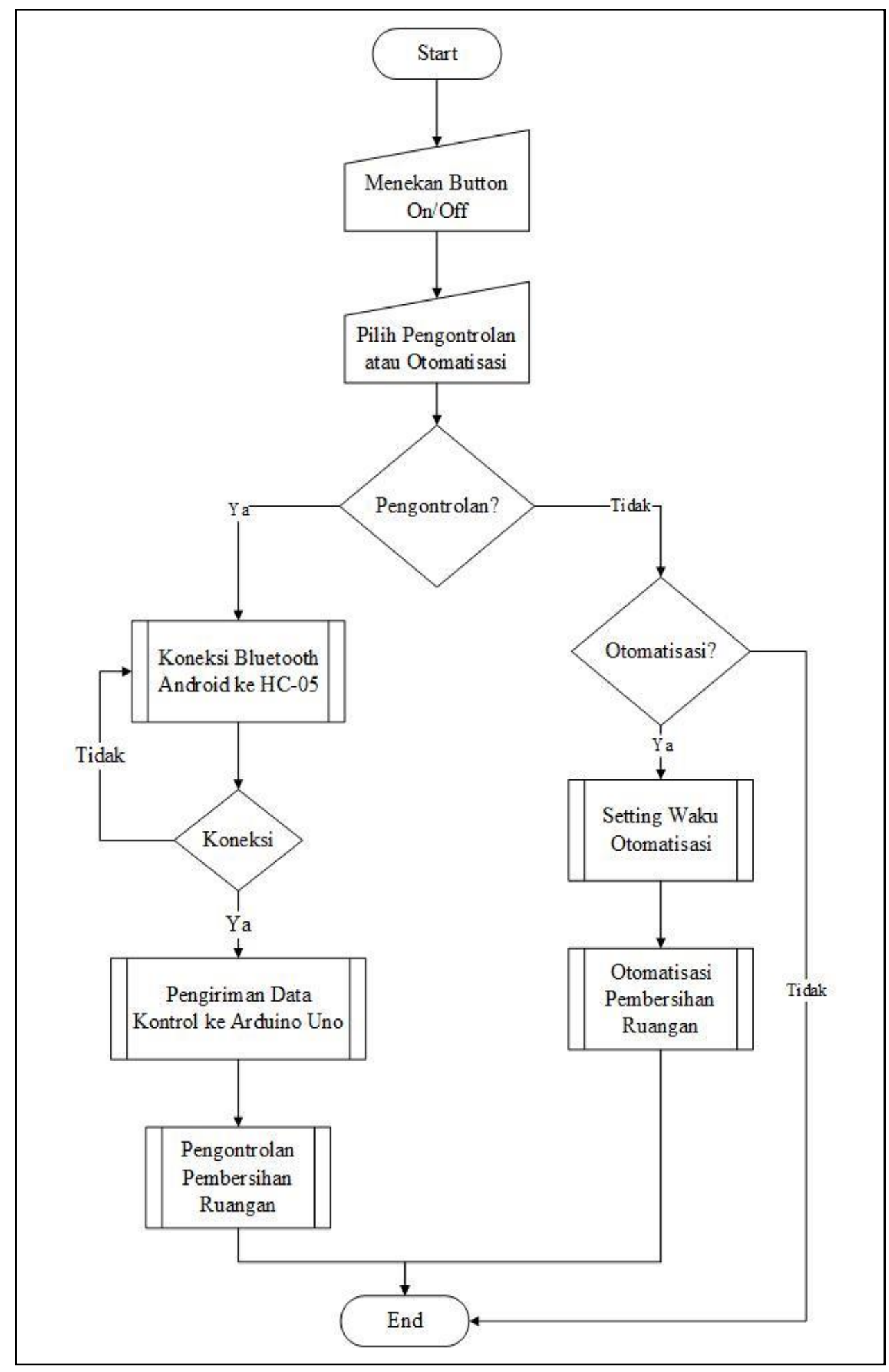

Gambar 9 Flowchart Sistem Keseluruhan

Perancangan antar muka ini merupakan rancangan antar muka aplikasi yang mengontrol robot. Perancangan antar muka ini hanya terdiri dari satu activity atau satu tampilan dan dua dialog. Dialog pertama adalah dialog koneksi yang akan 
muncul jika button connect diklik, Dialog kedua adalah dialog input waktu otomatisasi pembersihan ruangan yang akan muncul jika button waktu otomatisasi diklik.

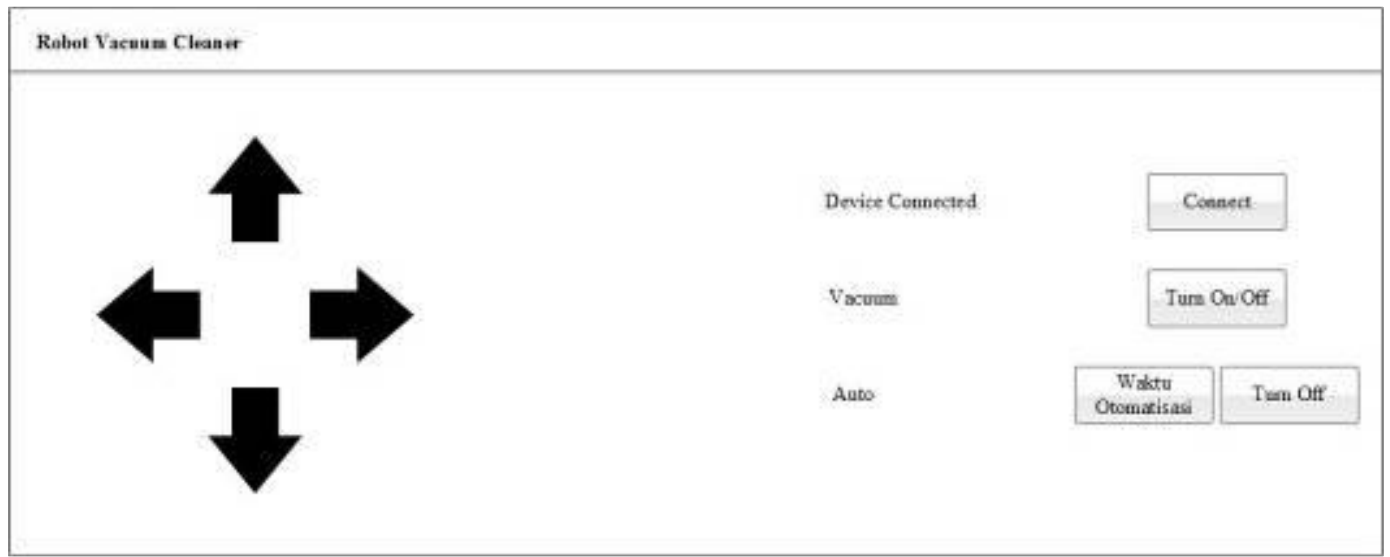

Gambar 10 Antar Muka Aplikasi

Setelah perancangan sistem elektronik, sistem mekanik, antar muka dan pemodelan sistem robot. Berikutnya adalah implementasi atau membangun robot dan membuat aplikasinya.

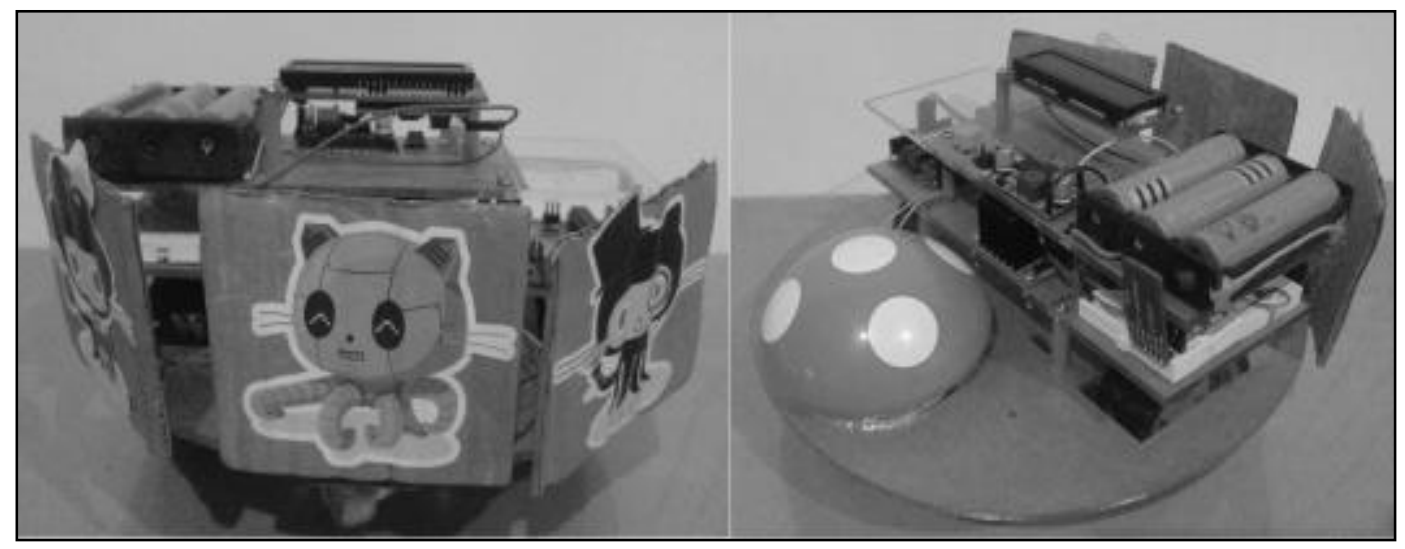

Gambar 11 Robot Bagian Depan dan Belakang

Pada gambar 11 bagian kiri, 3 kardus kecil depan berfungsi sebagai bumper dengan menggunakan 3 sensor limit switch. Apabila salah satu bumper menabrak maka robot akan mundur dan memilih jalan lain. 3 bumper ini hanya berfungsi pada otomatisasi pembersihan ruangan. Pada gambar 11 bagian kanan, komponen yang terletak di paling belakang adalah vacuum cleaner yang menggunakan $d c$ motor $3 \mathrm{v}$. 
Setelah merancang dan implementasi maka berikutnya adalah menguji perangkat lunak dan perangkat keras robot vacuum cleaner yaitu merupakan pengujian terhadap aplikasi android dan robot vacuum cleaner yang telah dibangun sudah sesuai dengan hasil yang diharapkan atau belum yang pengujiannya dapat dilihat di tabel 1 untuk pengujian aplikasi dan tabel 2 untuk pengujian perangkat keras. Metode yang digunakan untuk pengujian adalah metode blackbox yaitu pengujian yang dilakukan hanya mengamati hasil eksekusi melalui data uji.

Tabel 1 Pengujian Aplikasi Android

\begin{tabular}{|c|c|c|c|}
\hline No & Skenario Pengujian & Hasil yang diharapkan & Hasil Pengujian \\
\hline 1 & Klik buttonbluetooth & $\begin{array}{l}\text { Muncul Dialog "Select Device } \\
\text { to Connect" }\end{array}$ & Sesuai Harapan \\
\hline 2 & Klik button scan & $\begin{array}{l}\text { Mencari Bluetooth sekitar } \\
\text { yang belum paired, dan } \\
\text { muncul di Available Devices }\end{array}$ & Sesuai Harapan \\
\hline 3 & $\begin{array}{l}\text { Klik bluetooth yang } \\
\text { tedapat dibawah } \\
\text { available devices }\end{array}$ & $\begin{array}{l}\text { Pairing dengan } \text { Bluetooth } \\
\text { tersebut dan setelah pairing } \\
\text { sukses muncul di paired } \\
\text { devices }\end{array}$ & Sesuai Harapan \\
\hline 4 & $\begin{array}{l}\text { Klik Bluetooth yang } \\
\text { terdapat dibawah } \\
\text { paired devices }\end{array}$ & $\begin{array}{l}\text { Mengkoneksi } r \text { dengan } \\
\text { Bluetooth yang terdapat } \\
\text { dirobot. Jika sukses muncul } \\
\text { dialog "connection } \\
\text { succesfull". Jika gagal muncul } \\
\text { dialog "connection failed" }\end{array}$ & Sesuai Harapan \\
\hline 5 & $\begin{array}{l}\text { Lihat tulisan No } \\
\text { Device Connected }\end{array}$ & $\begin{array}{l}\text { Jika terkoneksi dengan } \\
\text { Bluetooth robot, muncul nama } \\
\text { Bluetooth robot. Jika tidak } \\
\text { terkoneksi dengan Bluetooth } \\
\text { robot, tulisan tetap no device } \\
\text { connected }\end{array}$ & Sesuai Harapan \\
\hline 6 & Klik Button Up & $\begin{array}{l}\text { Menggerakan robot maju ke } \\
\text { depan }\end{array}$ & Sesuai Harapan \\
\hline 7 & Klik Button Down & $\begin{array}{l}\text { Menggerakan robot munder } \\
\text { ke belakang }\end{array}$ & Sesuai Harapan \\
\hline
\end{tabular}




\begin{tabular}{|c|c|c|c|}
\hline 8 & Klik Button Left & $\begin{array}{l}\text { Menggerakan robot belok ke } \\
\text { kiri }\end{array}$ & Sesuai Harapan \\
\hline 9 & Klik Button Right & $\begin{array}{l}\text { Menggerakan robot belok ke } \\
\text { kanan }\end{array}$ & Sesuai Harapan \\
\hline 10 & $\begin{array}{l}\text { Lepas Klik } \text { dari } \\
\text { Button Up, Down, } \\
\text { Left, Right }\end{array}$ & Robot Berhenti di tempat & Sesuai Harapan \\
\hline 11 & $\begin{array}{ll}\text { Klik } & \text { Switch } \\
\text { vacuumon }\end{array}$ & $\begin{array}{l}\text { Menghidupkan vacuum } \\
\text { cleaner }\end{array}$ & Sesuai Harapan \\
\hline 12 & $\begin{array}{ll}\text { Klik } & \text { Switch } \\
\text { vacuumoff } & \end{array}$ & Mematikan vacuum cleaner & Sesuai Harapan \\
\hline 13 & $\begin{array}{l}\text { Klik button waktu } \\
\text { otomatisasi }\end{array}$ & $\begin{array}{lr}\text { Muncul dialog untuk } \\
\text { memasukkan waktu } \\
\text { otomatisasi dalam menit yang } \\
\text { diinginkan }\end{array}$ & Sesuai Harapan \\
\hline 14 & $\begin{array}{l}\text { Klik button send } \\
\text { yang terdapat di } \\
\text { dialog } \\
\text { otomatisasi waktu } \\
\text { pembersihan ruangan }\end{array}$ & $\begin{array}{l}\text { Mengirimkan data waktu yang } \\
\text { di input ke robot }\end{array}$ & Sesuai Harapan \\
\hline 15 & Klik button turn off & $\begin{array}{l}\text { Mengirimkan data waktu " } 0 \text { " } \\
\text { ke robot untuk menghentikan } \\
\text { otomatisasi robot }\end{array}$ & Sesuai Harapan \\
\hline
\end{tabular}

Tabel 2 Pengujian Robot

\begin{tabular}{|l|l|l|l|}
\hline No & Skenario Pengujian & \multicolumn{1}{|c|}{ Hasil yang diharapkan } & Hasil Pengujian \\
\hline 1 & Tekan switchon/off & $\begin{array}{l}\text { Jika tekan on robot } \\
\text { dihidupkan. Jika tekan off } \\
\text { robot dimatikan }\end{array}$ & Sesuai Harapan \\
\hline 2 & Tekan Button Merah & $\begin{array}{l}\text { LCD menampilkan 5 menit, } \\
10 \text { menit, 30 menit, 60 menit } \\
\text { dan waktu countdown } \\
\text { pemilihan waktu }\end{array}$ & Sesuai Harapan \\
\hline
\end{tabular}




\begin{tabular}{|l|l|l|l|}
\hline 3 & $\begin{array}{l}\text { Tunggu 5 detik } \\
\text { setelah menekan } \\
\text { button merah }\end{array}$ & $\begin{array}{l}\text { Robot akan menggunakan } \\
\text { waktu yang terdapat di LCD } \\
\text { untuk otomatisasi } \\
\text { pembersihan ruangan }\end{array}$ & Sesuai Harapan \\
\hline 4 & $\begin{array}{l}\text { Tunggu 5, 10, 30,60 } \\
\text { menit setelah robot } \\
\text { melakukan } \\
\text { otomatisasi }\end{array}$ & Robot akan berhenti & Sesuai Harapan \\
\hline
\end{tabular}

\section{KESIMPULAN}

Berdasarkan perancangan dan pengujian robot vacuumcleaner yang telah di bangun maka penulis dapat mengambil beberapa kesimpulan yaitu sebagai berikut:

1. Robot vacuum cleaner yang di bangun dapat di kontrol pengguna serta dapat menyetel waktu otomatisasi pembersihan ruangan.

2. Robot vaccum cleaner yang di bangun dapat otomatisasi dalam pembersihan ruangan.

3. Otomatisasi pembersihan ruangan kurang efisien karena tidak ada navigasi dalam pembersihan ruangan.

Setelah penulis merancang dan menguji robot vacuum cleaner, ada beberapa saran yang dapat diusulkan untuk mengembangkan robot vacuumcleaner yang dibangun adalah sebagai berikut:

1. Menambah raspberry pi dan kamera untuk menggunakan komputer vision sebagai sensor mendeteksi sampah dalam navigasi pembersihan ruangan.

2. Menambah charging port atau BMS (battery management system) agar baterai robot dapat di cas.

3. Menggantikan vacuum cleaner yang menggunakan $d c$ motor $6 \mathrm{v}$ atau $12 \mathrm{v}$ agar kekuatan menghisap sampah lebih besar

\section{DAFTAR PUSTAKA}

Ardhi Setya S.T., M.Kom. \& Dr. Ir. Sutiksno M.T., Perancangan dan Pembuatan Prototipe Alat Pembersih Lantai dengan Kendali dari Jaringan 
Bluetooth, 2016, [Online] Tersedia di:

lppm.stts.edu/publication/download?id=50, [diunduh: 20 Februari 2017]

Kadir Abdul, From Zero to a Pro Arduino, Penerbit Andi, 2015, Yogyakarta

Nugroho Adi, Analisis dan Perancangan Sistem Informasi dengan

Metodologi Berorientasi Objek, Informatika, 2004, Bandung

Tim EMS, Android All In One, PT Elex Media Komputindo, 2013, Jakarta

Vacuum Cleaner,[Online] Tersedia di:

https://en.wikipedia.org/wiki/Vacuum_cleaner[2017, Juli 23 / 22:53]

Zifkri Afwan, Hidayat Anton, Derisma, Rancang Bangun Robot Vacuum Cleaner Berbasis Mikrokontroler, 2015, [Online] Tersedia di:

eprints.dinus.ac.id/16467/50/SM114.pdf, [diunduh: 20 Februari 2017] 